\title{
The Development of Mathematical Problems in the Form of Animated Stories to Measure Students' Logical-Mathematical Intelligence
}

\author{
Dinar Aven Niaputri ${ }^{1,{ }^{*}}$ Budiyono ${ }^{2,}$ Diari Indriati ${ }^{3}$ \\ ${ }^{1}$ Postgraduate of Mathematics Education, Faculty of Teacher Training and Education, Universitas Sebelas \\ Maret Surakarta, Indonesia \\ ${ }^{2}$ Faculty of Teacher Training and Education, Universitas Sebelas Maret Surakarta, Indonesia \\ ${ }^{3}$ Faculty of Mathematics and Natural Sciences, Universitas Sebelas Maret Surakarta, Indonesia \\ *Corresponding author. Email: dinaraven@student.uns.ac.id
}

\begin{abstract}
The intelligence needed by students in solving mathematical problems is logical-mathematical intelligence. Logical-mathematical intelligence has six characteristics: classification, comparing, mathematical arithmetic operations, inductive reasoning, making hypotheses, and re-checking the hypotheses that have been created. This study aimed to produce a valid logical-mathematical intelligence-based test instrument on SPLDV material for class VIII SMP students. The type of research used is the type of research and development (R\&D). The development model used is the Budiyono development model with four stages, namely preliminary studies, product development, product efficacy testing, and dissemination and implementation. However, this research is limited only to product development. The instrument used is a questionnaire validation sheet covering aspects of content, construct, and language. Data analysis was carried out by describing the responses, suggestions, and input from the three validators. The results of the validators show that the average value of validity, difficulty, and discriminating power. They also show that the questions are good and valid. This indicates that the test instrument developed is ready to be used. This research is still limited to SPLDV material, and further researchers can develop other material test instruments so that students' mathematical, logical intelligence test instruments can be more diverse.
\end{abstract}

Keywords: Logical-mathematical intelligence, Instrument development, Validity test results.

\section{INTRODUCTION}

Mathematics is a medium to train students to think creatively, critically, logically, carefully, and thoroughly. Therefore, in learning mathematics, students must improve their reasoning and problemsolving abilities [1]. Students' ability to solve problems can be achieved through learning story questions. Story questions are one of the forms of questions presented in stories and associated with issues of daily life so that through learning story questions, it is hoped that students can understand the use of mathematics in everyday life [2]. Students' mistakes in solving story problems are because they do not understand the existing concepts. This lack of understanding of the concept is due to students having different levels of intelligence [3]. The intelligence needed by students in solving mathematical problems is logical-mathematical intelligence. Logicalmathematical intelligence has six characteristics: classification, comparing, mathematical arithmetic operations, inductive reasoning, making hypotheses, and re-checking the hypotheses that have been created [4]. The characteristics of people who have logicalmathematical intelligence can solve problems and arrange solutions to a problem in a logical order. Students with high logical-mathematical intelligence will develop problem-solving and numeracy skills more quickly to get good mathematics learning outcomes [5].

The relevant research that examines animated stories, namely the use of cartoons in a learning atmosphere, positively impacts student learning 
achievement [6]. One of the teachers stated that the audio-visual effect was very supportive of learning mathematics [7]. Mathematics learning with cartoons is generally more fun than ordinary learning, so that learning is more effective, and students are motivated to improve achievement in learning mathematics [8]. In addition, cartoons become as if they move and sound and can be an exciting story structure [9]. Relevant research regarding students' logicalmathematical intelligence, namely students' logical intelligence, can help students deal with learning difficulties [10]. In mathematics learning, logical intelligence can be used by students in solving mathematical problems and concretizing mathematical abstractions with logical and mathematical thinking [11]. Over some literature that has been reviewed, some gaps need to be investigated regarding the development of student problems in the form of animated stories to improve students' logicalmathematical intelligence.

One learning medium that is expected to create an exciting and fun learning atmosphere for students is learning videos involving audio-visual displays such as text, audio, visuals, graphics, and animations [12]. Nowadays, many 3D cartoon films are favored by the public, especially students. This proves that animated stories attract attention to anyone who watches them. There is also a moral impression presented in the animated story to be more beneficial [13].

This study aims to develop mathematical problems in animated stories to improve students' logicalmathematical intelligence. Mathematics teachers can use animated story media to visualize the issues presented in the material so that students are expected to understand better. To attract more students' attention, animated stories are presented in 3D. Considering the 2013 Curriculum, one of the models used is Problem Based Learning or problem-based learning. Then, learning media using 3D animated stories will be beneficial as a form of visualization of the problems presented to improve students' logicalmathematical intelligence.

\section{RESEARCH METHODOLOGY}

\subsection{Research Design}

This research is included in research and development (R\&D) research. Development research is a research method used to produce specific products and test the efficacy of these products against existing products [14]. The $\mathrm{R} \& \mathrm{D}$ research model used is the research model proposed by Budiyono with four stages namely preliminary studies, product development, product efficacy testing, and dissemination and implementation. There are three main steps at the preliminary study stage: initial research, needs analysis, and literature study. The product development phase consists of three phases: planning, initial product development, testing, and revision. On the other hand, the product efficacy testing stage compares the developed product with the previous product and follows the experimental research stage. The dissemination and implementation stage is the publication of the results of the development in scientific forums.

\subsection{Research Instruments}

The product development in this research is a valid test instrument designed to measure students' logical-mathematical intelligence in problem-solving. The development model used is the Budiyono development model with four stages, namely preliminary studies, product development, product efficacy testing, and dissemination and implementation [15]. Preliminary studies were conducted to identify students' Logical-Mathematical Intelligence problems directly in the field or through literature studies. Product development is done by compiling test instruments. Then, at the trial and revision stage, the researcher sent a test instrument and a validation sheet to the validator for validation. Afterward, the test instruments made improvements according to suggestions and comments from the validator. In the revised operational test and data collection, the developed test instrument trials were carried out. After that, at the dissemination and implementation stage, the final instrument that has been tested is disseminated.

\subsection{Data Collection Technique}

The data collection technique in this study is the collection of validity sheet data obtained from the validator. The validator will provide an assessment by giving a checkmark from the existing assessment aspects of the test questions with choices of very good (5), good (4), enough (3), less good (2), and not good (1). then, add up the total score of each validator, look for the average validity, and categorize the validity criteria of the questions presented in Table 1.

Table 1. Criteria for validity of test questions

\begin{tabular}{|c|c|}
\hline Score Interval & Validity Criteria \\
\hline $4 \leq X \leq 5$ & Very Valid \\
\hline $3 \leq X<4$ & Valid \\
\hline $2 \leq X<3$ & Less Valid \\
\hline
\end{tabular}




\begin{tabular}{|c|c|}
\hline $1 \leq X<2$ & Invalid \\
\hline After validators were carried out, the researcher
\end{tabular}
conducted the test instruments to students to determine the Validity, Reliability, Discriminating power, and Level of difficulty of the questions.

\subsubsection{Item Validity} $[16]$

$\boldsymbol{r}_{x y}=\frac{\boldsymbol{N} \sum X \boldsymbol{Y}-\left(\sum X\right)\left(\sum \boldsymbol{Y}\right)}{\sqrt{\left\{N \sum X^{2}-\left(\sum X^{2}\right)\right\}\left\{N \sum \boldsymbol{Y}^{2}-\left(\sum \boldsymbol{Y}^{2}\right)\right\}}}$

Descriptions:

$r_{x y}=$ Correlation Coefficient of each item

$\mathrm{N}=$ Many test subjects

$\mathrm{X}=$ Score item questions

$\mathrm{Y}=$ Total score

The results of the $r_{x y}$ calculation are then compared with the rtable. If $r_{x y}>r_{\text {table }}$ has a significant level of $5 \%$, the question is valid. In other words, if $r_{x y}<r_{\text {table }}$, the question is said to be invalid.

\subsubsection{Reliability}

Reliability for the description test questions used the Alpha formula: [16]

$$
r_{11}=\left(\frac{n}{n-1}\right)\left(1-\frac{\sum \sigma_{i}^{2}}{{\sigma_{i}^{2}}^{2}}\right)
$$

Descriptions:

$\mathrm{r}_{11}=$ Question reliability

$\mathrm{n}=$ Number of questions

$\sum \sigma_{i}{ }^{2}=$ Total score variance of each item

$\sigma_{i}^{2}=$ Total variance

The calculation results are compared with rtable with a significant level of 5\%. If $r_{11}>r_{\text {table }}$, the test instrument is said to be reliable.

\subsubsection{Discriminating Power}

Table 2. Discriminating power category

\begin{tabular}{|c|c|}
\hline Discriminating Power & Category \\
\hline$D \geq 0.40$ & Very good \\
\hline $0.30-0.39$ & Good \\
\hline $0.20-0.29$ & Enough \\
\hline$D \leq 0.19$ & Not good \\
\hline
\end{tabular}

The discriminating power formula for the test instrument is in the form of description questions:

$$
D P=\frac{\bar{X}_{A}-\bar{X}_{B}}{\text { Skor Maks }}
$$

Descpriptions:

DP $=$ Discriminating Power

$\overline{X_{\mathrm{A}}}=$ Upper group average.

$\overline{X_{\mathrm{A}}}=$ Lower group average.

According to the terms of the discrimination index, discriminating power is classified into four categories (Table 2):

\subsubsection{Difficulty Level}

The formula used to analyze the level of difficulty:

$$
\text { TK }=\frac{\bar{X}}{\text { Skor maks }}
$$

Descriptions:

TK = Difficulty Level

$\bar{X}=$ Average score per question item.

Terms of the difficulty index category [16] as follow Table 3:

Table 3. Categories of difficulty levels

\begin{tabular}{|c|c|}
\hline Difficulty Levels & Categories \\
\hline $0.00<\mathrm{TK} \leq 0.30$ & Hard \\
\hline $0.31<\mathrm{TK} \leq 0.70$ & intermediate \\
\hline $0.71<\mathrm{TK} \leq 1.00$ & Easy \\
\hline
\end{tabular}

\subsection{Data Analysis}

The stages of data analysis in this study are test instruments. The test instrument is ready to be used after going through the validation and revision process based on comments and suggestions for improvement from the validator. If the developed instrument is valid, reliable, and contains good points, it is ready to be used. Usually, the item is said to be good if the discriminatory power and difficulty level is good.

\section{RESULT}

\section{1 Preliminary studies}

At this stage, preliminary research is carried out to find out the fundamental problems in learning mathematics. There are still many students who have difficulty solving mathematical problems, especially in working on story problems in mathematical models. One of the materials that students get is the TwoVariable Linear Equation System (SPLDV) material. Based on the results of an interview with one of the teachers at SMP N 1 Purwoharjo. Students have difficulty receiving and understanding the material delivered online during distance learning, and educators feel less effective with this. $\mathrm{He}$ also 
explained several things, one of which is the logicalmathematical intelligence of students, which is essential in learning mathematics. However, there are still some students who are still lacking. This can be seen when students still have difficulty in solving problems. Educators have made an effort to train logical intelligence by increasing practice questions to make students more qualified. Logical-Mathematical intelligence was chosen as an approach to the test instrument developed to improve students' mathematical problem-solving abilities with more varied forms of questions. In addition, intelligence is effectively, as possessed by mathematicians and scientists [17].

\subsection{Product Development}

The product development stage begins by compiling the development of a test instrument as many as four essay test questions. Furthermore, the researcher submitted the instrument and validation sheet to the validators to determine their validity by considering content, construction, and language. Table 4 is a description of the assessment criteria for the test questions along with the scores from the three

Table 4. Criteria for assessment of test questions and scor result

\begin{tabular}{|c|c|c|c|c|}
\hline \multirow{2}{*}{ Aspect } & \multirow{2}{*}{ Assessment Criteria } & \multicolumn{3}{|c|}{ Score } \\
\hline & & 1 & 2 & 3 \\
\hline Contents & 1. The items are under the indicators and the question grid & 4 & 5 & 5 \\
\hline \multirow[t]{2}{*}{ Construction } & 1. The subject matter is formulated coherently, concisely, and firmly & 5 & 4 & 5 \\
\hline & 2. Items according to the ability of junior high school students & 5 & 4 & 5 \\
\hline \multirow[t]{4}{*}{ Language } & 1. Formulation of questions using good and correct Indonesian rules & 3 & 4 & 5 \\
\hline & $\begin{array}{l}\text { 2. Formulation of questions using simple, communicative, and easy-to-use } \\
\text { language }\end{array}$ & 4 & 4 & 5 \\
\hline & 3. The question formulation does not provide multiple interpretations & 2 & 4 & 5 \\
\hline & $\begin{array}{l}\text { 4. The suitability of the sentence with the level of thinking and reading ability } \\
\text { of students }\end{array}$ & 4 & 5 & 4 \\
\hline
\end{tabular}

related to the ability to use numbers and logic

Here (Figure 1) is an example of a test instrument product development before it was revised. and an example of the display of questions in the form of 3dimensional animation can be seen in Figure 2

1. Fitri bought three books and two pencils for Rp11,500. Prilly bought four books and three pencils for Rp. 16,000.00. If Ika buys two books and one pencil, the amount of money to be paid is...

2. The price of two pairs of shoes and three pairs of sandals is Rp. 175,000.00, while the cost of three pairs of shoes and four pairs of sandals is $\mathrm{Rp}$. $255,000.00$. The price of a couple of shoes and two pairs of sandals is...

3. Dita bought four books and three pencils for $\mathrm{Rp}$. 14,400.00. Meanwhile, Dini bought six notebooks and five pencils for Rp. 11,200. Determine the price Dita must pay if she adds two books and three pencils to her shopping spree!

4. Rini and Doni's total money is Rp. 75,000.00, while their difference is Rp. 5,000.00. How much money do Rini and Doni have?

Figure 1 Unrevised test instrument validators.

The results of the assessments of the three validators in Table 4 are then calculated on average to determine the criteria for the validity of the questions. The results of the calculation of the mean and validity criteria can be seen in Table 5 .

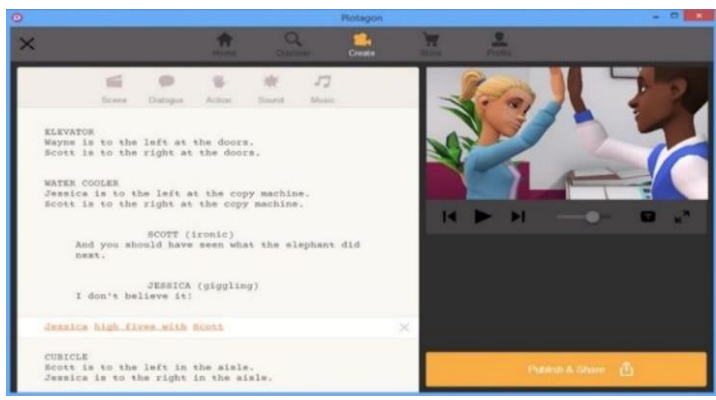

Figure 2 3D Design sample display

Table 5. Validity test results from experts

\begin{tabular}{|c|c|c|c|}
\hline \multirow{2}{*}{ Validator } & \multicolumn{3}{|c|}{ Average Score } \\
\cline { 2 - 4 } & Content & Construction & Language \\
\hline V1 & 4 & 5 & 5 \\
\hline V2 & 5 & 4 & 4 \\
\hline V3 & 5 & 5 & 5 \\
\hline
\end{tabular}




\begin{tabular}{|c|c|c|c|}
\hline $\begin{array}{c}\text { Average } \\
\text { Score }\end{array}$ & 4.67 & 4.67 & 4.67 \\
\hline Criteria & Very Valid & Very Valid & Very Valid \\
\hline
\end{tabular}

The assessment by the expert presented in Table 5 is an assessment after the questions have been revised. Here (Figure 3) is an example of a revised test instrument product development.

1. The price of two pairs of shoes and three pairs of sandals is Rp. 175,000.00, while the cost of three pairs of shoes and four pairs of sandals is Rp. 255,000.00. The price for a couple of shoes and two pairs of sandals is...

2. Dita bought four books and three pencils for Rp. 14,400.00. Meanwhile, Dini bought six books and five pencils for Rp. 11,200. Determine the price Dita must pay if she adds two books and three pencils to her shopping spree!

3. Rini and Doni's total money is Rp. $75,000.00$ while their difference is Rp. 5,000.00. How much money do Rini and Doni have?

\section{Figure 3 Revised test instrument}

The revised questions were then tested to see other aspects. After the test instrument is tested, the next step is to calculate the questions' item validity (Table 6), reliability, level of difficulty (Table 7), and discriminating power.

Table 6. Results of item validity test

\begin{tabular}{|c|c|c|c|}
\hline $\begin{array}{c}\text { Question } \\
\text { Number }\end{array}$ & $\begin{array}{c}\text { Value of } \\
\text { r count }\end{array}$ & $\begin{array}{c}\text { Value of } \\
\text { r table }\end{array}$ & Category \\
\hline 1 & 0.664 & 0.369 & Valid \\
\hline 2 & 0.724 & 0.369 & Valid \\
\hline 3 & 0.682 & 0.369 & Valid \\
\hline
\end{tabular}

In the reliability test, the value obtained is 0.796 , so that the questions are said to be reliable.

Table 7. Result of difficulty level test

\begin{tabular}{|c|c|c|}
\hline $\begin{array}{c}\text { Question } \\
\text { Number }\end{array}$ & Calculation Value & Criteria \\
\hline 1 & 0.63 & Intermediate \\
\hline 2 & 0.57 & Intermediate \\
\hline 3 & 0.68 & Intermediate \\
\hline
\end{tabular}

In the discriminatory test, the results obtained were 0.32 for item number 1 , which was categorized as good, and 0.26, which was categorized as sufficient for item number 2 . For item number 3 , it was 0.37 , which was categorized as good. Because the test instrument consists of three questions and has good discriminating power, the questions are said to have good discriminating power. Based on the test results of validity, reliability, level of difficulty, and discriminatory power, the test instrument developed was good.

\subsection{Dissemination and Implementation}

At this stage, the researcher compiled articles to disseminate information about developing a valid test instrument to measure students' logical-mathematical intelligence.

\section{DISCUSSION}

The development of test instruments is guided by the test grid [18]. The test instrument used is in the form of description questions. With description questions, teachers can know and understand students' ability to solve problems. One of the description questions that can be applied is a question related to problem-solving. The instrument is declared very valid in the construction aspect, which is categorized with the validity criteria. Likewise, the instrument was declared very valid according to the validity criteria with the content and language aspects. Judging from the three elements assessed, the test instrument made is valid to be used [19]. The validator validates the instruments that have been compiled. According to the validity criteria, the instrument developed is valid if it is categorized as valid or very valid [20]. The instrument was classified based on the valid criteria of the question after several revisions were created based on the validator's comments and suggestions for improvement [21]. The results of the validation calculation concluded that the items were declared valid. The instrument question was then analyzed for its reliability test and obtained a result of 0.796 and was reported reliable. The difficulty level of the items is included in the easy and medium categories. The items have a reasonably good discriminating power, so the questions are good to use. on the subject matter of SPLDV.

\section{CONCLUSION}

Based on the validation results of the three validators in terms of content, construction, and language, it can be concluded that the SPLDV material test instrument developed was declared valid to be used to measure students' mathematical logical intelligence in problem-solving. Based on the test results of validity, reliability, level of difficulty, and distinguishing power, the researcher can conclude that 
the questions are good and feasible to use. This research is still limited to SPLDV material, and further researchers can develop test instruments to measure students' mathematical logical intelligence with various materials.

\section{REFERENCES}

[1] Slameto. Belajar dan Faktor-Faktor yang Mempengaruhinya. Jakarta: Rineka Cipta, 2010.

[2] Visitasari, Riska., Siswono, T. Y. E. Kemampuan Siswa Memecahkan Masalah Berbentuk Soal Cerita Aljabar Menggunakan Tahapan Analisis Newman. Jurnal Pendidikan,2013.

[3] Rahmania, L. dan Rahmawati. Analisis Kesalahan Siswa dalam Menyelesaikan Soal Cerita Persamaan Linier Satu Variabel. Jurnal Matematika dan Pendidikan Matematika, 2016.

[4] Salim, Affandi Amat, dkk. Profil Pemecahan Masalah Sistem Persamaan Linear Dua Variabel Siswa Kelas VIII SMPN Model Terpadu Madani Palu ditinjau dari kecerdasan Logis Matematis. Jurnal Elektronik Pendidikan Matematika Tadulako, 2016, Vol 04, No 02.

[5] Baharudin. Teori Belajar dan Pembelajaran. Jogjakarta: Ar-Ruzz Media, 2007.

[6] Akamca, G. Ö., A. M. Ellez, dan H. Hamurcu. Effects of computer aided concept cartoons on learning outcomes. Procedia Social and Behavioral Sciences, 2009, hal. 296-301.

[7] Turan, B. The Opinions of Teacher on The Use of Cartoon Character In The Mathematics Lesson. Procedia Social and Behavioral Sciences, 2014, hal. 1(141): 1386-1391.

[8] Supriyadi. Penggunaan Kartun Matematika dalam Pembelajaran Matematika. Jurnal Pendidikan Dasar, 2008, hal. 10:1-6.

[9] Andriana, J., B. E. Purnama. Pembuatan Animasi Flim Kartun dengan Komputer Multimedia. Jurnal Speed-Sentra Penelitian Engineering dan Edukasi, 2009, hal. 19(1):1119.

[10] Yaumi, Muhammad. Pembelajaran Berbasis Multiple Intelligences. Jakarta: Dian Rakyat, 2012.

[11] Gunawan, Adi W. Born to be a Genius. Jakarta: Gramedia Pustaka Utama, 2003.

[12] Sugihartono, A.S., dan B. Herryprilosadoso. Animasi Kartun: dari Analog sampai Digital. Yogyakarta: Indeks, 2010.
[13] Azizah, S. Pengembangan Media Pembelajaran Matematika Berbentuk Cerita Animasi Berbasis Plotagon di Kelas 2 Sekolah Dasar. Jurnal Kajian Pendidikan Matematika, 2016, hal. 180 192.

[14] Sugiyono. Metode Penelitian \& Pengembangan, Bandung:Penerbit Alfabeta, 2017.

[15] Budiyono. Pengantar Metodologi Penelitian Pendidikan. Surakarta: UNS Press, 2017.

[16] S. Arikunto, Dasar-Dasar Evaluasi Pendidikan. Jakarta: Bumi Aksara, 201

[17] Librianti, V. D., Sunardi, \& Sugiarti, Titik. Kecerdasan Visual Spasial dan Logis Matematis dalam Menyelesaikan Masalah Geometri Siswa Kelas VIII A SMP Negeri 10 Jember. Artikel Ilmiah Mahasiswa , 2015.

[18] S. Ndiung dan M. Jediut, Pengembangan instrumen tes hasil belajar matematika peserta didik sekolah dasar berorientasi pada berpikir tingkat tinggi, Prem. Educ. J. Pendidik. Dasar dan Pembelajaran, vol. 10, no. 1, hal. 94, 2020, doi: 10.25273/pe.v10i1.6274.

[19] A. Wardani, M. N. Arkan, dan A. Suyudi, Pengembangan Instrumen Tes Keterampilan Pemecahan Masalah Pokok Bahasan Listrik Dinamis, J. Kependidikan Betara, vol. 1, no. 1, hal. 14-19, 2020.

[20] S. R. Hidayat et al., Pengembangan Instrumen Tes Keterampilan Pemecahan Masalah pada Materi Getaran, Gelombang, dan Bunyi, $J$. Penelit. Pengemb. Pendidik. Fis., vol. 3, no. 2, hal. 157-166, 2017, doi: 10.21009/1.03206.

[21] D. S. Setiana, Pengembangan Instrumen Tes Matematika Untuk Mengukur Kemampuan Berpikir Kritis, J. Pendidik. Surya Edukasi, vol. 4, no. 2, hal. 35-48, 2018. 